Revista de Ensino em Artes, Moda e Design

Dossiê 5

As fontes de pesquisa para moda. Uma aproximação interdisciplinar e arquivista da história da moda: pesquisa e ensino.

DOI: $10.5965 / 25944630332019068$

\title{
DA COLEÇÃO AO ARQUIVO: CONSIDERAÇÕES SOBRE O ACERVO DE RUI SPOHR
}

From the collection to the archive: notes about
Rui Spohr's personal collection

De la collection au dossier: considérations concernant l'acquis de Rui Spohr

Renata Fratton Noronha ${ }^{1}$

1 Doutora em História pela PUCRS e Mestre em Processos e Manifestações Culturais da Universidade Feevale. Foi estagiária do Museu Galliera durante período de realização do Master em Mode et Création na Université de la Mode- Lumière Lyon 2. Ė professora do curso de Moda da Universidade Feevale.

E-mail: ffratton@gmail.com | Lattes: http://lattes.cnpq.br/7710532275762424 | Orcid: http://orcid.org/0000-0002-2838-2405 


\title{
Resumo
}

Neste artigo, retomo alguns pontos abordados em minha tese de doutorado, que buscou compreender como o costureiro gaúcho Rui Spohr (1929-2019) construiu sua imagem e seu espaço de atuação a partir de Porto Alegre. Levando em consideração o trabalho de enquadramento da memória, conforme Michael Pollak, busco demonstrar como o processo de organização da narrativa e da autoimagem de Rui Spohr se relaciona à constituição de seu acervo pessoal, um lugar de memória que, revisitado, se abre a novas possibilidades.

Palavras-Chave: Moda. Memória. Arquivos de moda. Rui Spohr.

\begin{abstract}
In this paper, some point from my PhD thesis are revisited. As it's aim was to which comprehend how Rui Spohr (1929-2019), a couturier from the South Brazil, built his image and a fashion field from Porto Alegre. Taking into account the concepts from Michael Pollak, I demonstrate how Rui Spohr's process of builting a personal memory, as well as his self-image, is related to the organization of his personal collection, a place of memory that, revisited, opens up to new possibilities.
\end{abstract}

Key-words: Fashion. Memory. Fashion archives. Rui Spohr.

\section{Resumé}

L'objectif de cette article est revenir dans certains points abordés sur ma thèse de doctorat. La thèse a eû comme but comprendre comment Rui Spohr (1929-2019) a forgé son image de couturier au sud du Brésil, à Porto Alegre - ville où il vit et travaille jusqu'à nos jours. Ayant comme pont de départ les idées de Michael Pollack, c'est possible de vérifier le travail d'encadrement de sa mémoire ainsi que les dialogues qu'il établit spécialmenent pour contituer une collection privée, comprise de différents documents qui temoignent également, sa trajectoire. Cette collection est um lieu de mémoire qui permet aussi une ouverture vers des nouvelles possibilités de recherche et aussi de création.

Mots-clés: Mode. Mémoire. Archives de mode. Rui Spohr 


\section{INTROUÇÃO}

No universo da moda, a palavra coleção é utilizada para designar, conforme Doris Treptow (2013), a reunião ou conjunto de peças de roupas e acessórios que possuam alguma relação harmônica entre si - do ponto de vista estético e comercial. Além disso, as coleções têm fabricação e entrega previstas para uma determinada época do ano, e são elaboradas tendo em vista, geralmente, um público-alvo específico.

Coleção também é um termo associado à definição e organização do espaço dos museus. Reúne objetos de diferentes naturezas - artísticos, historiográficos, botânicos, zoológicos - que compõem esses espaços, abertos ao público e voltados para aquisição, estudo, exposição e transmissão de patrimônios materiais e imateriais.

Aproximar os dois termos, que pertencem a ambientes aparentemente distantes, além de ajudar a perceber a moda em sua dimensão material, oferece indícios a respeito da organização do acervo, no caso em análise, de Rui Spohr. O costureiro gaúcho, que ganhou visibilidade nacional ao participar das ações da Rhodia durante a FENIT, ao longo da vida catalogou, organizou, classificou - sempre com a ajuda da esposa, Doris Spohr - materiais e documentos que funcionaram como um registro da carreira.

Dessa forma, o objetivo deste artigo é perceber como este acervo constitui um lugar de memória, que ajuda a sustentar a narrativa que Rui constrói para si, assim como traz à tona outras histórias - e possibilidades. É possível, ainda, destacar peculiaridades, assim como o tratamento dispensado a determinados eventos e objetos.

A seguir, serão examinadas algumas das coleções e documentos que embasaram minha pesquisa de doutorado. Tais registros reforçam os discursos autobiográficos de Rui e, ao mesmo tempo, proporcionam uma abertura promissora: como fontes de pesquisa, podem assumir uma nova performance à medida que remetem não apenas aos tempos de Rui, mas também aos tempos da sociedade onde viveu e do campo em que atuou.

\section{A IMPORTÂNCIA DO ARQUIVAMENTO NA NARRATIVA DE RUI SPOHR}

Rui Spohr teve uma atuação longeva. Se o objetivo fosse transformá-lo em um verbete, pontuando datas e eventos importantes conforme uma ordem cronológica, isso poderia ser feito da forma que segue.

Batizado como Flávio Spohr, nasceu na cidade de Novo Hamburgo, em 1929. No final dos anos 1940, passou a assinar uma coluna sobre moda na Gazeta de Novo Hamburgo. Em 1949, apresentou o seu primeiro desfile em um baile local da União dos Estudantes.

Em 1952, após a morte do pai, partiu para Paris, onde estudou nas escolas da Chambre Syndicale de la Haute Couture e Guerre-Lavigne (atual Esmod). Retornou ao Brasil em 1956 e instalou-se em Porto Alegre. Entre 1957 e 1958, manteve a coluna "O que há de novo" no jornal A Hora. Em 1960, casou-se com Doris Uhrl, então sua assistente. Entre os anos de 1962 e 1964, integrou o time de costureiros da Rhodia Têxtil, cujo conjunto de ações publicitárias buscavam promover a cultura nacional, associando sua produção à criação de uma moda brasileira.

Nos anos 1970, inaugurou loja própria na Rua Miguel Tostes, em Porto Alegre, misto de boutique e atelier, onde passou a oferecer prêt-à-porter com sua assinatura, 
além de roupas sob medida. No final da década de 1980, iniciou atividades de docência em um curso de estilismo voltado para o setor coureiro-calçadista.

No início dos anos 1990, comemorou quarenta anos de carreira com uma exposição fotográfica e comandou desfiles-show abertos ao público. A partir dos anos 2000, seu trabalho passou a figurar em mostras e exposições, tornando-se alvo de pesquisas acadêmicas e homenagens: os testemunhos de sua carreira ultrapassam sua ação contemporânea e o transformam em referência. Em 2015, lançou uma coleção-cápsula e um livro para colorir, que retomam seu passado e sua imagem de sucesso. Em 2017, deu termo às atividades da alta-costura. Em 2018, a loja da Rua Miguel Tostes foi fechada, encerrando sua carreira de maneira definitiva. Faleceu em 30 de abril de 2019.

Em 1997, Rui Spohr lançou sua autobiografia, Memórias alinhavadas (1997) SUGIRO REFERENCIAR, escrita em parceria com Beatriz Viegas-Faria. O livro conduz, inicialmente, à experiência de Rui como estudante em Paris - detalhes de sua chegada, com duas malas ao exíguo quarto de "5ème étage, sans ascenceur", em Montparnasse, onde morou; sua instalação definitiva em Porto Alegre; e a construção de seu espaço profissional. Por fim, evoca fatos significativos de sua infância.

Existe ainda, nessa obra, a preocupação de relatar episódios tidos como importantes ou inusitados, tais como a influência da figura de Evita Perón, então primeira-dama argentina e vestida por Dior; a participação nos desfiles promovidos pela Rhodia na década de 1960; ou, ainda, a história da noiva que dizia: "O meu véu vai cair!". Por vezes, Rui se preocupa em informar o leitor, em tom pedagógico, sobre suas visões acerca do papel de profissional da moda - o que chama de "a minha verdade" -, assim como registrar desabafos e conselhos. A autobiografia de Rui, ao aglutinar um discurso que já vinha sendo consolidado ao longo de sua carreira, delimita marcos e alude a "fatos de memória" - os quais, segundo Michel Pollak (1992), são "[...] expressões que remetem mais a noções de memória, ou seja, a percepções da realidade, do que à factualidade positivista subjacente a tais percepções" (POLLAK, 1992, p. falta número de página). Esses fatos de memória passam a ser constantemente retomados, possibilitando um processo de enquadramento. A memória enquadrada, ensina Pollak, é mais específica do que a memória coletiva: não é construída de maneira arbitrária, produz um discurso organizado. Ainda para Pollak (1989, p. falta número de página), "[...] o trabalho de enquadramento da memória se alimenta do material fornecido pela história. Esse material pode sem dúvida ser interpretado e combinado a um sem-número de referências associadas".

Alessandra Vaccari (2015), no âmbito da História e da Teoria da Moda, defende que os discursos produzidos pelos designers de moda sejam utilizados como fonte de pesquisa, pois, se reconhecidos de maneira crítica, ajudam a compreender como esses profissionais escrevem e subscrevem uma história da moda, para além de contar aspectos da própria vida. ${ }^{1}$

Dessa forma, a autobiografia de Rui, encarada como fonte de pesquisa, funciona como um lugar de memória - no qual a totalidade de sua história de vida se encontra condensada. Conforme a perspectiva proposta por Vaccari, relatos autobiográficos podem ser compreendidos para além de uma seleção de fatos que, narrados, ajudam a consolidar uma imagem de si. O gesto de escrever, organizar e tornar públicas as me-

\footnotetext{
1 Philippe Artières considera a autobiografia como prática de arquivar a própria vida, ressaltando que "[...] não só escolhemos alguns acontecimentos como os ordenamos ém uma narrativa; a escolha e classificação dos acontecimentos determinam o sentido que queremos dar às nossas vidas" (ARTIÉRES, 1998, p. 9).
} 
mórias é também um processo de arquivamento. A seleção, ordenação e classificação dos acontecimentos em uma narrativa determinam o sentido a ser dado à própria vida.

No caso de Rui, fica ainda evidente que arranjos e rearranjos desta narrativa são embasados nos registros e documentos que compõem seu acervo pessoal. Os materiais arquivados, ao mesmo tempo em que ajudam a desvelar o processo de construção de uma imagem de si no campo simbólico, através de traços materiais (documentos, roupas, fotografias) constituem uma espécie de memória física que ratifica a veracidade daquilo que é relatado em sua autobiografia. Revisitados, os registros ajudam a criar novas camadas para esta narrativa já constituída e conhecida.

A organização desses materiais arquivados segue uma lógica mais ou menos intuitiva: pastas classificam, ano a ano, os modelos executados sob-medida e também registros fotográficos, artigos da imprensa e correspondências. Somam-se a esse material roupas, acessórios, aviamentos e uma vasta coleção de revistas.

A partir do interesse de pesquisadores de diversas áreas, o acervo Rui Spohr passou por um levantamento detalhado e, dessa forma, foi dividido em quatro coleções: coleção objetos, coleção textual, coleção iconográfica e coleção têxtil. A coleção de objetos se constitui de materiais em metal, madeira e tecido. A coleção textual é formada por documentos em suporte papel de diversas origens, como, por exemplo, recortes de jornal, livros, cadernos, revistas, folders, folhas avulsas e pastas. A coleção iconográfica compreende desenhos feitos em lápis grafite e pastel, além de fotografias preto e branco e coloridas - referentes ao período decorrido entre a década de 1940 e os dias atuais.

Dessa forma, o conjunto de coleções pode ser encarado como um arquivo de fontes diversificadas, integrando sua história de vida à história da sociedade em que viveu e atuou. Apesar de a seleção dos objetos ter-se iniciado pela vontade do próprio Rui, a organização passou a ser tarefa de Doris Spohr, sua esposa. Como guardiã, ajudou a elaborar um discurso acerca dos objetos guardados que acabou sendo incorporado à "história oficial" de Rui. ${ }^{2}$

\section{O ACERVO COMO (AUTO)REFERÊNCIA}

Alessandra Vaccari observa que, nos últimos anos, as empresas de moda vêm valorizando seus arquivos - que, muitas vezes, passam a ser utilizados com o objetivo de reforçar uma imagem corporativa ou, ainda, alimentar o processo criativo de seus designers (VACCARI, 2012).

Um exemplo pode ser visto no documentário Dior and I, de 2014, dirigido por Frédéric Tcheng. Nele, o trabalho criativo de Ralf Simons - em sua estreia na maison Christian Dior - ganhou protagonismo, deixando evidentes algumas diferenças: Dior entrou para a história da moda como costureiro-criador que se abastecia das memórias da infância no jardim da família, em Granville, - com seus desenhos, "transformava as mulheres em flor". Já Simons, diretor artístico, em nenhum momento traçou um croqui. Ordena seu referencial criativo às imagens constituídas pelo próprio Dior.

Em dado momento, Ralph Simons observa um conjunto de fotografias, ou ainda faz desfilar uma modelo, portando originais de Dior, criados em 1950. Ao visitar uma

2 Como observa Angela do Castro e Gomes, guardião ou mediador da memória atua como: "[...] um 'narrador privilegiado' da história do grupo a que pertence e sobre o qual está autorizado a falar. Ele guarda/possui as 'marcas' do passado sobre o qual se remete, tanto porque se torna um ponto de convergência de histórias vividas por muitos outros do grupo (vivos e mortos), quanto porque é o 'colecionador' dos objetos materiais que encerram aquela memória” (GOMES, 1996, p.23). 
exposição no Centre Georges Pompidou, não hesita em telefonar para o artista Sterling Ruby e pedir permissão para transformar sua obra em tecido. Aos poucos, a primeira coleção de alta-costura de Ralf Simons para Christian Dior se revela a partir dos arquivos que compõem a memória da marca. Elin e Colin Renfrew (2010) chamam esse processo - que consiste em analisar coleções anteriores, ou mesmo antigas, em busca de inspiração - de arquivismo, É uma maneira de atualizar a marca, a partir de suas próprias referências estéticas ou modelos marcantes.

Guardadas as proporções, em outubro de 2015 houve uma iniciativa de reatualização da marca Rui, onde se observou processo muito semelhante ao exibido no documentário que registrou o trabalho de Ralf Simons para Dior: elementos de arquivo foram trazidos à tona para incorporar criações no presente. (FIGURA 1)

Figura 1: Coleção Cápsula Croquis. Ricardo Lage, 2015.

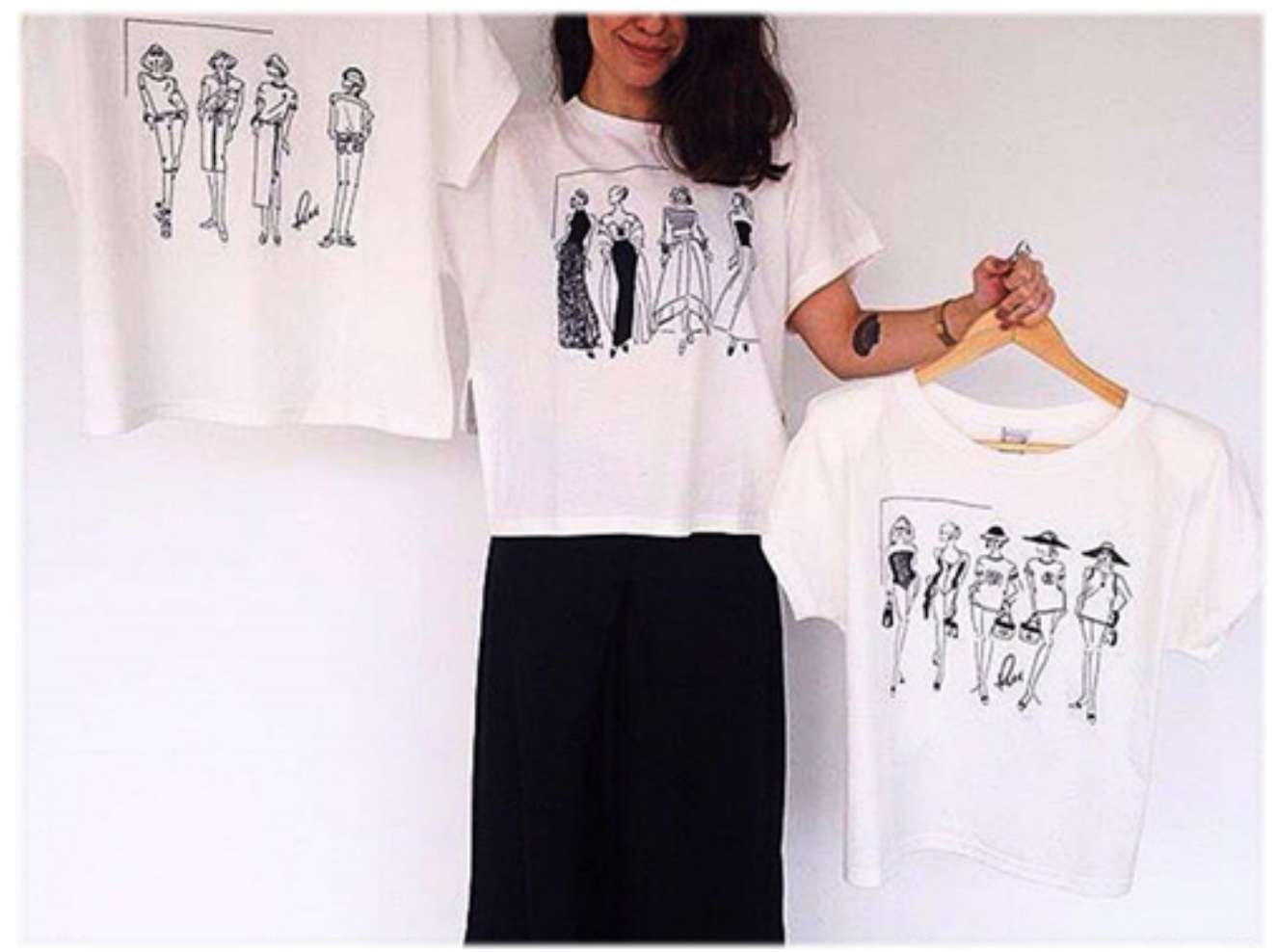

Fonte: Acervo Rui Spohr.

A linha foi composta por um lenço, uma camiseta e um livro para colorir, evidenciando justamente aquilo que aproxima o costureiro do gestual do artista: seus croquis. Os desenhos utilizados como estampa foram os que ilustraram os primeiros anos da colaboração de Rui no jornal Correio do Povo. ${ }^{3}$ Especialmente para a camiseta, foi adaptada uma modelagem do período, enfatizando o conceito de releitura.

As peças foram comercializadas pela Loja Pandorga, espaço destinado a criadores e pequenas marcas de moda, design e artes visuais em início de trajetória (BORTHOLUZZI, 2015). Ao se colocar ao lado dos jovens criadores, Rui acenou para a vanguarda e também para o público jovem. A série de imagens produzidas para o lançamento ${ }^{4}$ dos produtos integrou passado e presente ao apresentar novas proposições a partir de pe-

3 Rui manteve uma coluna semanal no referido jornal entre os anos de 1996 e 2017.

40 conjunto de iniciativas foi coordenado pelo publicitário Eduardo Vanoni. A Loja Pandorga ocupava dois endereços na cidade, um na Rua Miguel Tostes, pouco distante da maison de Rui, e outro no Instituto Ling - Centro Cultural cujo edifício foi projetado pelo arquiteto Isay Weinfeld. A Pandorga encerrou suas atividades em dezembro de 2017. 
ças conservadas no acervo de Rui. Tratou-se de uma maneira de dizer que seu posto de referência como profissional da moda local permanecia - e teria continuidade.

Apesar dos esforços, Rui Spohr encerrou definitivamente a produção de seu prêt-à-porter em 2017. No ano seguinte, encerrou também as atividades dos ateliês de roupas sob medida. Mesmo sem ter nomeado um sucessor, as referências estilísticas de Rui seguiram sendo atualizadas sob o olhar de alunos das faculdades de moda.

O curso de Design de Moda da Uniritter, em Porto Alegre, estimula seus alunos a adotar uma marca local como referência para o desenvolvimento de seus projetos criativos, seguindo metodologias projetuais orientadas para a moda. ${ }^{5}$ Nesse contexto, em 2014, a designer Melissa Assis buscou referências no acervo de Rui Spohr para realizar sua coleção para a disciplina Projeto de Moda II. As peças fizeram parte do desfile DNA Sul, promovido por aquela Universidade (FIGURA 2).

Figura 2: Desenvolvimento de coleção inspirada em Rui. Melissa Assis, 2014.

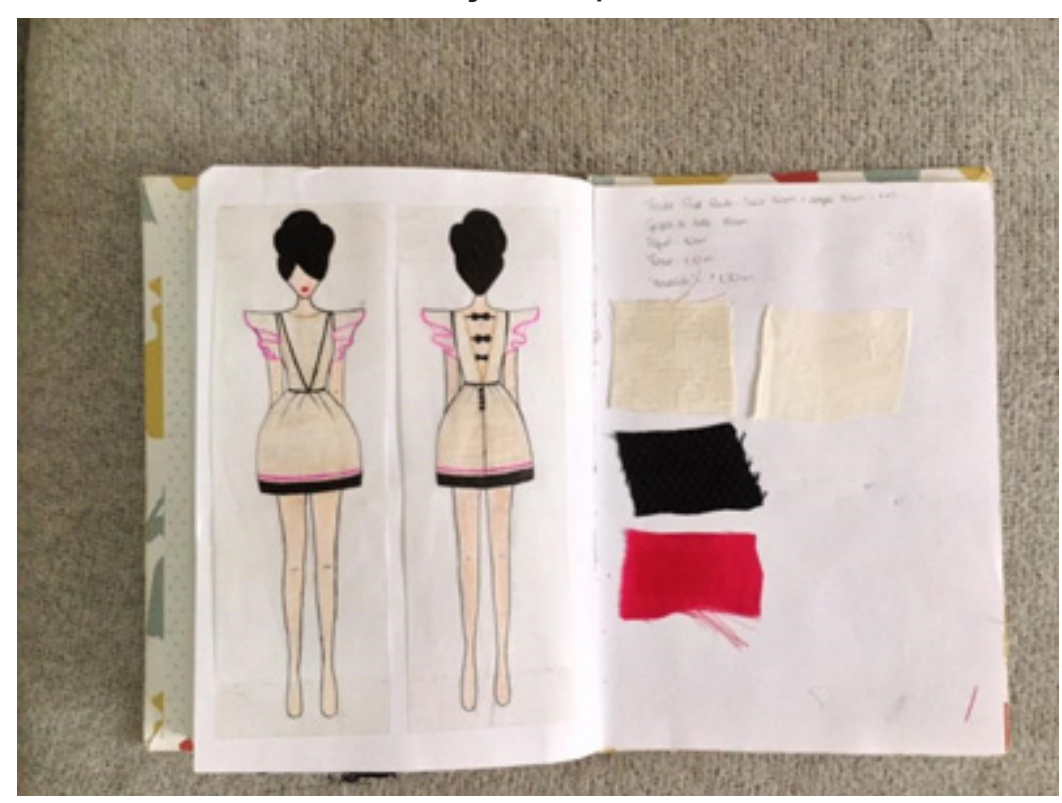

Fonte: Arquivo pessoal Melissa Assis.

Em seu processo criativo, a designer buscou traços marcantes do estilo de Rui que, recombinados com suas preferências estilísticas, resultaram em novos arranjos que congregavam o estilo de ambos. A vanguarda encontrou a tradição, para, juntas, criarem novas possibilidades (FIGURA 3).

5 Este conjunto de metodologias fundamenta o ensino do Design de Moda atual e leva em consideração aspectos técnicos, mercadológicos e também criativos na produção de novos modelos. A pesquisa de imagens, composta por referências e tendências de moda, podendo misturar informações de arquivos e da imprensa, por exemplo, é fundamental na etapa criativa - que envolve um estudo de viabilidade dos modelos. 
Figura 3: Modelo de Melissa Assis, 2014.

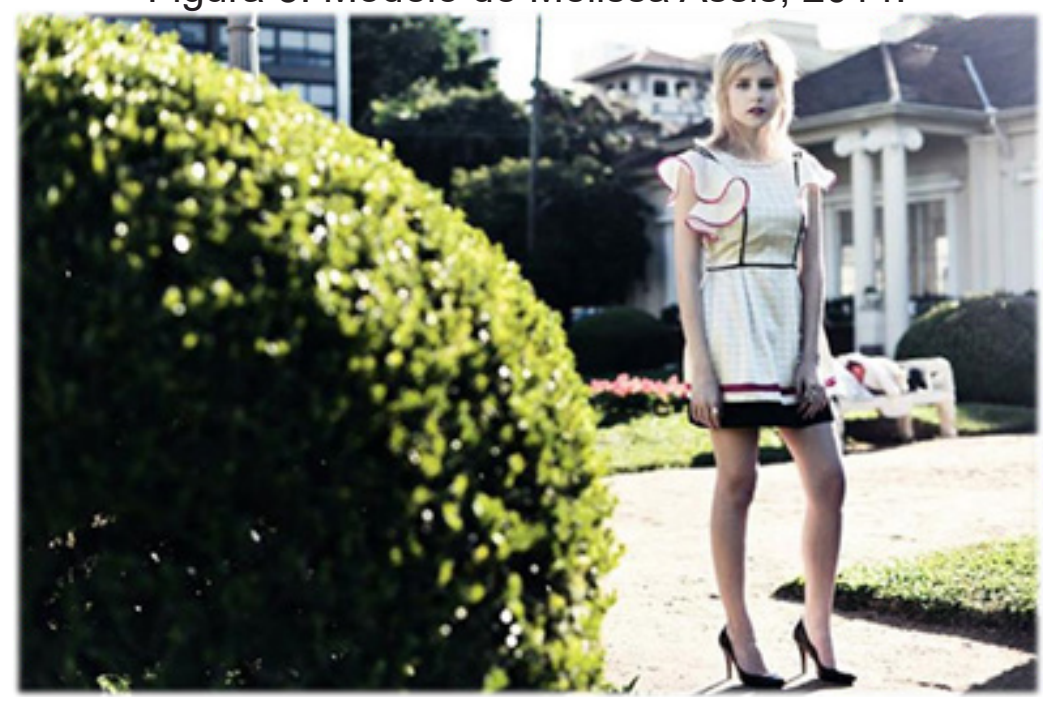

Fonte: Arquivo pessoal Melissa Assis.

\section{UM ESPAÇO PARA (OUTRAS) HISTÓRIA(S)}

Além de espaço para consulta de designers de moda, o acervo de Rui passou a receber pesquisadores de diferentes áreas. Revelou, assim, não apenas as histórias inseridas em uma narrativa ligada à trajetória de Rui, mas também outras, que se organizam em torno de suas criações.

Essa possibilidade ficou evidente na pesquisa que originou a dissertação da antropóloga Aline Lopes Rochedo. Ela biografou um vestido criado por Rui, que pertenceu a Heloisa Pinto Ribeiro. O vestido, adquirido em 1971, foi usado novamente por Heloisa em seu aniversário de 80 anos, em 2011. Além disso, a peça foi indicada por Rui como representativa de seu trabalho para integrar a exposição Moda, realizada no Museu de Arte Brasileira (MAB), da Fundação Armando Alvares Penteado (FAAP-SP), em 2012. Rochedo, além de observar as mudanças de status do vestido, viu que o ingresso em um espaço museológico encorajou Rui a reivindicar seu lugar como artista, potencializando disputas em torno do objeto (ROCHEDO, 2015).

Apesar de não integrar o acervo, o vestido "da Heloisa"6 é representativo de uma série de outras peças que, no contexto, remetem a suas usuárias ou possuem uma espécie de história própria. Nesse sentido, podem ser observados, por exemplo, o vestido "da Célia" ou ainda o vestido "da Madi", que estão ambos inventariados no acervo de Rui Spohr.

O vestido "da Célia" foi vestido pela jornalista Célia Ribeiro no início dos anos 1960. Chama mais atenção pelo seu material do que pelo seu desenho: é um modelo preto, estilo fourreau ${ }^{7}$, feito com uma espécie de palha utilizada na confecção de chapéus. Esse material foi doado por uma cliente (fazia parte do antigo estoque de sua mãe, que era chapeleira ${ }^{8}$ ) e posteriormente transformado em vestido. Em 2013, o modelo foi 6 Fato curioso, também abordado na pesquisa de Rochedo, é que no acervo de Rui há outro modelo, criado à mesma época do vestido "da Heloisa", feito com o mesmo material e semelhante em estilo. Porém, sua importância ficou preterida uma vez que não foi vendido - ou seja, não teve usuária - e ainda não passou por todas as instâncias de consagração do modelo biografado. Em resumo: não teve uma vida social marcante.

7 Vestido com modelagem reta e ajustada, que pode ser longo ou curto. (N. A.)

8 Conforme Doris SPOHR, a chapelaria teve origem no final do século XIX, funcionando em uma casa, na Rua Fernando Machado, 513. Em 2011, a referida casa abrigou a Casa M, que integrava o circuito de atividades da $8^{a}$ Bienal do Mercosul. Os materiais importados ficaram guardados até serem reencontrados na década de 1960 e doados a Rui. Além do vestido, foram feitas saias e outros modelos, porém apenas o vestido "da Célia" retornou ao acervo. 
fotografado para uma edição especial do caderno feminino "Donna", do jornal Zero Hora, que homenageou Rui Spohr. Na legenda da imagem, lê-se: "este vestido de gala tem sua originalidade no material: palha preta, usada para fazer chapéus. Rui ganhou de uma chapeleira que havia fechado sua produção". Ou seja, além de levar a assinatura do Rui, a distinção de sua usuária e a raridade do material criaram novas camadas de valores e temporalidades ao modelo (FIGURA 4).

Figura 4: Vestido usado por Célia Ribeiro, 2013.

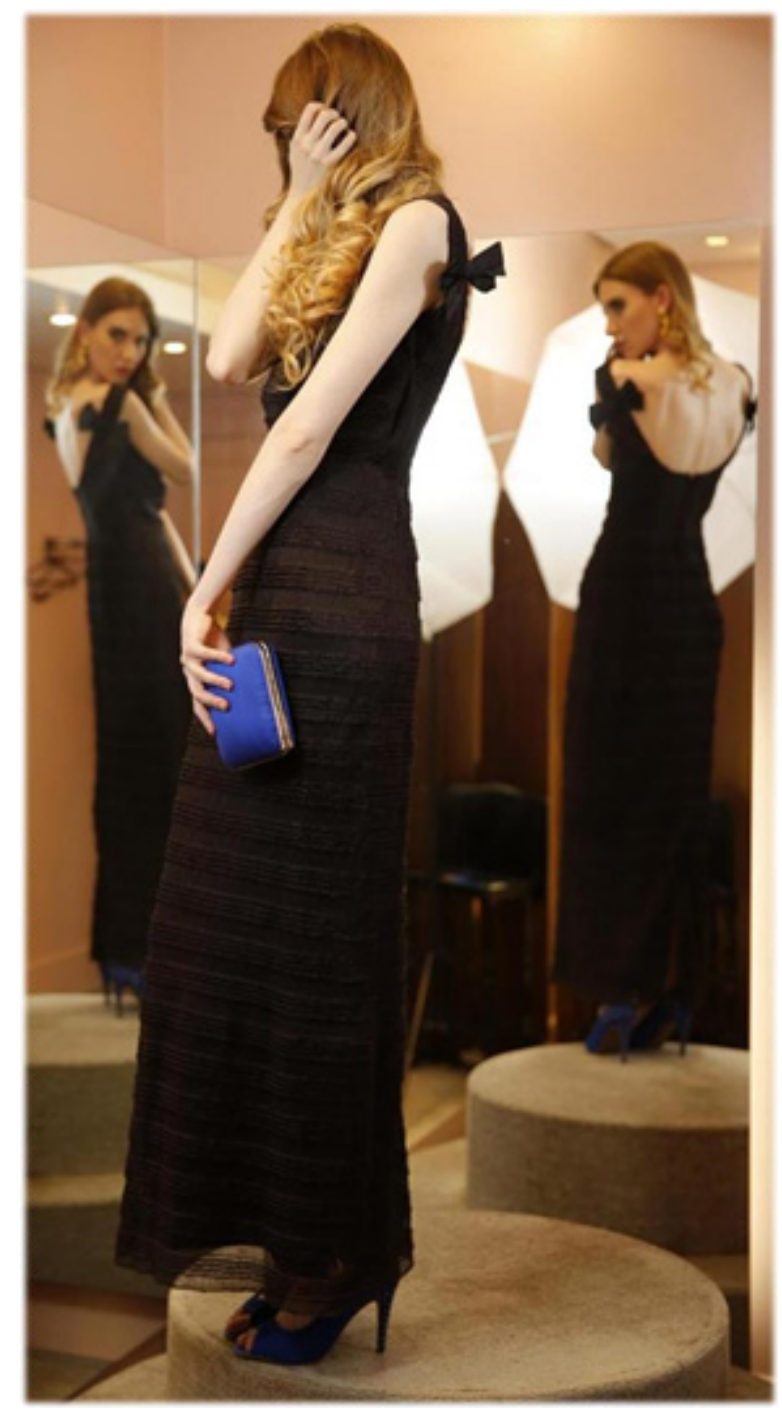

Fonte: Jornal Zero Hora.

Já o vestido "da Madi" foi uma criação de Rui para o evento Agulhas da Alta Moda, no ano 2000. Idealizado por Jô Clemente em benefício da APAE de São Paulo, o evento reuniu mais de 50 costureiros de todo o Brasil. Do Rio Grande do Sul, Rui e Luciano Baron foram os representantes convidados. O modelo preto, com corpete colorido, bordado com uma técnica chamada "pintura de agulhas" chama a atenção pelo movimento de 143 roletês, que substituem mangas longas. 
Figura 5: Rui Spohr e Madeleine Muller, 2000.

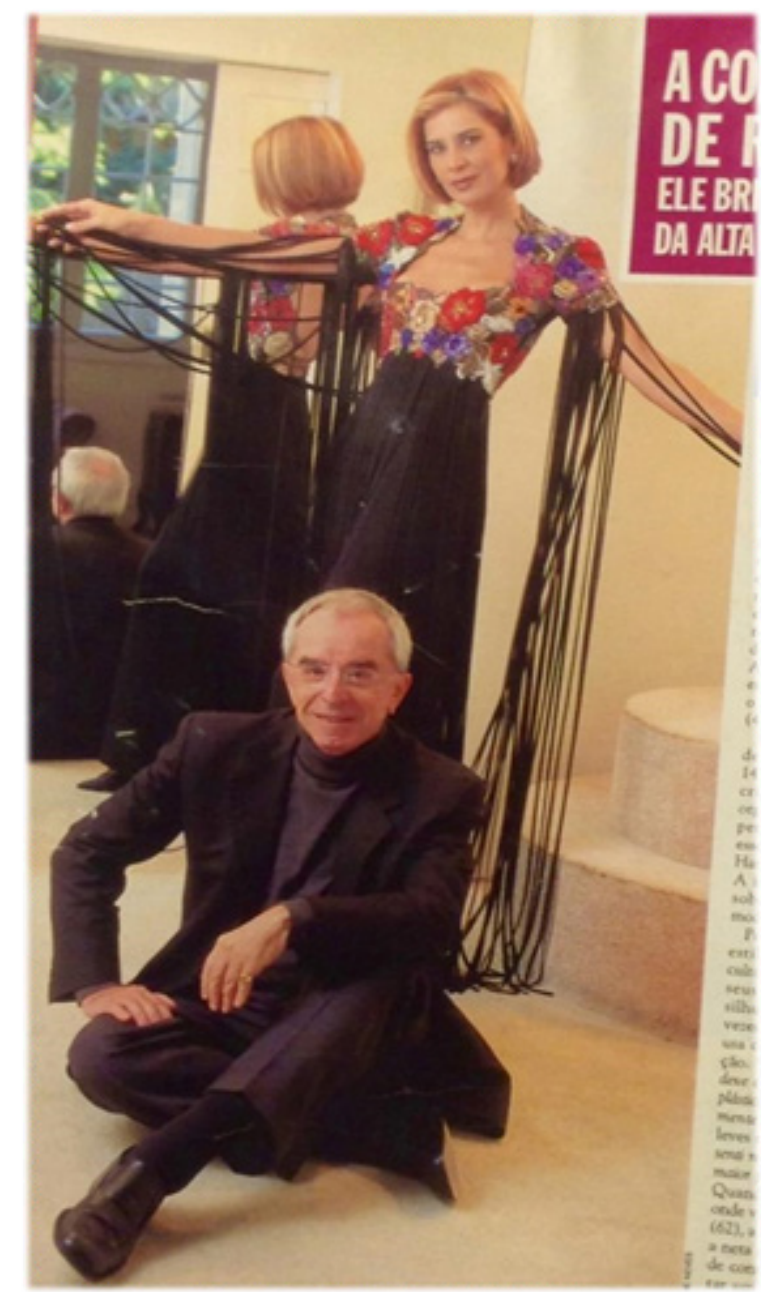

Fonte: Revista CARAS.

O vestido foi usado pela modelo Madeleine Muller $^{9}$ (a Madi) no mesmo ano, em uma matéria para a Revista Caras (FIGURA 5).

À época, Muller disse sentir "que o vestido a escolheu", pois foi convidada a desfilá-lo em vários momentos de sua carreira e também da carreira de Rui:

Cada vez que eu entrava no vestido, eu era uma outra mulher. E parece que ele ia se transformando, acompanhando as minhas mudanças identitárias e sempre me representando de alguma forma. Aquele vestido tem uma vida própria. Eu me sentia parte dele e ele parte de mim também.

Ao refletir sobre as roupas, seus usos e sua circulação, o antropólogo Peter Stallybrass, em O casaco de Marx (2004), toma como ponto de partida o casaco de seu falecido amigo, Allon White. Para Stallybrass, habitadas pelos nossos corpos, as roupas nos constituem, de certa forma, como indivíduos: portam memórias e fazem pensar sobre a relação entre as coisas como objetos de uso.

Como observa o também antropólogo Daniel Miller, a forma como a nossa sociedade se organiza em relação às roupas, principalmente antes da Revolução Francesa,

\footnotetext{
9 Madeleine Muller começou a desfilar para Rui aos 17 anos. Segundo ela, Rui foi o responsável pelo seu cabelo curto (estilo Louise Brooks). Tornou-se uma modelo conhecida no circuito local, chegando a ser selecionada para uma apresentação de Paco Rabanne em Porto Alegre, no final dos anos 1990. Além da carreira de modelo, atua como produtora de moda e, recentemente, dedica-se à área acadêmica, em estudos que versam sobre moda e sustentabilidade. Madeleine Muller é, também, mestre em Ciências da Comunicação pela Universidade Fernando Pessoa e autora do livro Admirável moda sustentável - vestindo um novo tempo (2018).
} 
são determinantes para elas serem tratadas de maneira a corresponder a uma identificação ou a conter um significado. Essa forma corroborou, inclusive, para que a abordagem da indumentária, como maneira de compreender as sociedades e seu modo de vida em determinada época, fosse julgada como superficial:

O conceito de pessoa, a percepção do eu e a experiência de ser um indivíduo são radicalmente diferentes em tempos diferentes e em lugares diversos, e parcialmente em relação às disparidades de indumentária [...]. O vestuário desempenha papel considerável e atuante na constituição da experiência particular do eu, numa determinação do que é o eu (MILLER, 2013, p. 63).

Retomando as ideias de Stallybrass para aproximá-las às de Miller, é possível dizer que vivemos em uma "sociedade de roupas", ou seja, os valores de troca assumem a forma de roupas. Elas passam a funcionar como um meio de incorporação e sua necessidade ultrapassa um caráter funcional: é também simbólica.

Dessa forma, o vestido "da Madi”, apesar de não lhe pertencer, acabou por carregar também memórias que se misturam à sua atuação como modelo: guarda uma espécie de história própria e oculta. Ao integrar o acervo, os registros dão conta especialmente da participação de Rui naquele evento. Apesar de o vestido ter sido usado por outras modelos, a relação de Madi com ele ultrapassa esse espaço narrativo.

\section{CONSIDERAÇÕES FINAIS}

A constituição do acervo Rui Spohr contém suas intenções de arquivar a própria vida, zeladas por Dóris Spohr, sua esposa. Como lugar de memória, reforça a narrativa condensada em sua autobiografia, Memórias alinhavadas (1997), uma vez que os materiais guardados foram retomados quando da escrita do livro. Pelo fato de a autobiografia ser uma seleção de fatos, ordenados de maneira a dar sentido a uma história de vida, o conjunto de materiais guardados também faz parte deste processo seletivo.

Na construção de uma imagem de si, Rui gerenciou uma série de discursos, o que colaborou para o trabalho de enquadramento de sua memória, pois reordenou suas referências, atualizou fatos e incorporou a materialidade de suas criações. Quando a história de sua vida passa incorporar novas histórias, amplia os significados das próprias ações, atribuindo à sua atuação uma força mítica.

Ao dar conta da história de Rui, o acervo acaba por reunir documentos e objetos que ultrapassam sua trajetória. As memórias nele contidas não são apenas de Rui, mas se relacionam a ele. Os objetos e documentos oferecem uma abertura: podem se tornar pontos de partida para novas investigações traçadas a partir do vestir - e de suas memórias. Podem ainda adquirir novos sentidos se reordenados e incorporados ao processo criativo de outros profissionais.

\section{REFERÊNCIAS}

ARTIÉRES, Philippe. Arquivar a própria vida. Estudos Históricos, Rio de Janeiro, v. 11, n. 21, p. 9-34, jul. 1998. Disponível em: http://bibliotecadigital.fgv.br/ojs/index.php/reh/ article/view/2061. Acesso em: 05 set. 2019.

BORTHOLUZZI, Juliana. O consumo acelerado direcionando o sistema da moda: o cluster criativo Pandorga loja coletiva. MODA DOCUMENTA - MODAE SOCIEDADE: percursos diversos, 5., São Paulo. Anais eletrônicos [...]. São Paulo: MIMO, 2015. Disponível em: http://www.modadocumenta.com.br/anais/5-Moda-Documenta_07-Sessao-Temati- 
ca-Moda-e-Sociedade-percursos-diversos.php. Acesso em: 05 set. 2019.

GOMES, Angela de Castro. A guardiã da memória. Acervo: revista do arquivo nacional, Rio de Janeiro, v. 9, n. 1-2, p. 17-30, jan./dez. 1996. Disponível em: https://cpdoc.fgv.br/ producao_intelectual/arq/538.pdf. Acesso em: 05 set. 2019.

MILLER, Daniel. Trecos, troços e coisas, estudos antropológicos sobre a cultura material. Trad. Renato Aguiar. Rio de Janeiro: Ed. Zahar, 2013.

POLLAK, Michael. Memória, esquecimento, silêncio. Estudos Históricos, Rio de Janeiro, v. 2, n. 3, p. 3-15, jun. 1989. ISSN 2178-1494. Disponível em: http://bibliotecadigital.fgv.br/ojs/index.php/reh/article/view/2278. Acesso em: 21 fev. 2019.

POLLAK, Michael. Memória e identidade social. Estudos Históricos, Rio de Janeiro, v. 5, n. 10, p. 200-215, jul. 1992. ISSN 2178-1494. Disponível em: http://bibliotecadigital.fgv. br/ojs/index.php/reh/article/view/1941. Acesso em: 21 Fev. 2019.

RENFREW, Colin; RENFREW, Elinor. Desenvolvendo uma coleção. Porto Alegre: Bookman, 2010.

ROCHEDO, Aline Lopes. Do croqui à academia: a biografia cultural de um vestido. 2015 Dissertação (Mestrado em Antropologia Social) - Programa de Pós-Graduação em Antropologia Şocial, Universidade Federal do Rio Grande do Sul, Porto Alegre, 2015. Disponível em: https://lume.ufrgs.br/handle/10183/131647. Acesso em: 05 set. 2019.

SPOHR, Rui; VIEGAS-FARIA, Beatriz. Memória Alinhavadas. Porto Alegre: Artes e Ofícios, 1997.

STALLYBRAS. Peter. O casaco de Marx: roupas, memória e dor. Belo Horizonte: Autêntica, 2004.

TREPTOW, Doris. Inventando Moda: planejamento de coleção. São Paulo: ed. da autora, 2013.

VACCARI, Alessandra. Arquivos, arquivismo e design de moda: uma experiência prática. Revista dObras, Florianópolis, v.5, n.12, 2012, p.50-57.

VACCARI, Alessandra. Autobiografias de designers de moda como ferramenta para pesquisa histórica. Modapalavra, Florianópolis, ano 8, n. 16, p. 8, jul-dez 2015. Disponível em: http://revistas.udesc.br/index.php/modapalavra/article/view/1982615x0816201 5005/4636. Acesso em: 22 fev. 2019.

Recebido em: 06/08/2019

Aceito em: 20/08/2019

DOI: http://dx.doi.org/10.5965/25944630332019068 